\title{
YOUTHS' INVOLVEMENT IN OIL PALM (ELAEIS GUINEENSIS) FRUIT PROCESSING ACTIVITIES
}

\author{
Julius Olatunde AYINDE ${ }^{1, *}$, Michael FAMAKINWA ${ }^{1}$, \\ Babatunde Opeyemi AKEREDOLU ${ }^{1}$ \\ *E-mail: tundeyjoy@yahoo.com; jayinde@oauife.edu.ng
}

Received: Aug. 18, 2020. Revised: Nov. 17, 2020. Accepted: Dec. 02, 2020. Published online: Jan. 29, 2021

\begin{abstract}
This study assessed the youths' involvement in oil palm fruit processing activities in Ondo State, Nigeria. It described the socio-economic characteristics of youths involved in oil palm fruit processing activities, determined their level of involvement, examined their perception and identified constraints associated with their involvement. Multistage sampling procedure was employed to select 120 respondents from the study area. Interview schedule was employed to collect relevant data, which was analysed with SPSS software package. Descriptive statistics were used to summarise the data while inferential statistics were used to draw inference on hypothesis. The results show that majority $(63.3 \%)$ were male, $95.8 \%$ had formal education with a mean age of $27.2 \pm 2.7$ years. Picking of fresh fruit bunches $(\bar{x}=$ 2.71), packaging $(\bar{x}=2.60)$ and gathering of bunches $(\bar{x}=2.50)$ were the major activities youth involved in. Higher percentage $(57.9 \%)$ of the youth had favourable perception towards involvement in oil palm fruit processing
\end{abstract}

activities. Lack of modern processing facilities $(\bar{x}=3.65)$ and funds/inadequate credit facilities $(\bar{x}=3.65)$ were the prime constraints to their involvement. Number of labour $(\mathrm{r}=0.7460 ; p \leq 0.01)$ and income $(\mathrm{r}=0.601 ; p \leq 0.01)$ of the respondents were significantly related to youth involvement. The study concluded that youth had moderate involvement in oil palm processing activities. However, agricultural development stakeholders like government should provide adequate and functional credits facilities to these youths to encourage their involvement.

Keywords: constraints; participation; processing; perception, socio-economic.

\section{INTRODUCTION}

Youth constitute the major human resource for agriculture and technology innovation development in every country (Nwachukwu, 2008). They are one of the greatest assets and major catalyst for change that any nation can mobilize for its national

\footnotetext{
${ }_{1}$ Department of Agricultural Extension and Rural Development, Obafemi Awolowo University, Ile-lfe, Osun State, Nigeria
} 
development through participation in agriculture (Valerie, 2009). According to National Population Commission (NPC, 2013), Nigerian youth was estimated to be almost half of her population and escapulates youth as individuals between 15 and 35 years of age. Bahaman et al. (2010) and Alao et al. (2014) refers to youth as men and women that are young with the abundance of energy and strength both mentally and physically. They possess both positive and negative attributes, which predominantly distinguish them from the adults. They are the most exuberant, the sharpest in memory, the most talented, the most innovative and the healthiest in most societies (Alabi and Famakinwa, 2016). Yet, they remain the bedrock on which every nation's development thrives. According to Aphunu and Atoma (2010), cited in Thomas and Eforuoku (2016), noted that the farming population in Nigeria is aging and is becoming practically impossible for this aged generation dominating agricultural sector to deliver the expected productivity that will meet the food needs of the evergrowing population.

Oil palm (Elaeis guineensis) is a common cash crop cultivated by farmers in Nigeria; the crop is important because it has been proved that it could serves as a means of livelihood for many rural families. It originated from West Africa within the tropical rainforest and it is indigenous to the Nigerian coastal plains (Eze et al., 2014; Olagunju, 2008). It is a versatile tree crop with almost all parts of the tree being useful and of economic value. Its essential components are used for household and industrial purposes include the fruits, fronds, leaves, trunk and roots. One major way of obtaining the economic values of oil palm is processing the palm fruits to palm oil and other products, which include palm kernel oil, palm wine, palm kernel cake and broom (Akangbe et al., 2011). Nwalieji and Ojike (2018) opined that the production and processing of oil palm constitute very important sources of income and employment to many rural dwellers.

According to Olagunju (2008), several million smallholders are spread over an estimated area of 1.67 million hectares in the southern part of Nigeria, with about $80 \%$ of production coming from dispersed smallholders farmers (https://www. modishproject.com/assessment-wome n-palm-processing/). Small-scale oil palm processing is predominant among processors in Nigeria, which is mainly through traditional methods (Olagunju, 2008). Although palm fruit produces palm oil and palm kernel oil as the two distinct oils, which are important in World Trade (Alabi et al., 2020, USDA, 2000), palm oil is the most useful and important product, which is used in the production of soaps and other detergents, while palm kernel oil, which is extracted from the nut, is also useful in the manufacture of margarine and oilbased confectioneries (Alabi et al, 2020; Koledoye and Deji, 2015). 


\section{J.O. AYINDE, M. FAMAKINWA, B.O. AKEREDOLU}

Nigeria was the world largest producers and exporters of palm oil in the early $1900 \mathrm{~s}$ to the $1960 \mathrm{~s}$, accounting for more than $40 \%$ of global output and $82 \%$ of its export earnings (Alabi et al., 2020). By the end of the twentieth century, Nigeria has lost her position to Malaysia, which is now largest producer of palm oil in the world, but at present Nigerian palm oil harvest had reduced to about $7 \%$ of the world production due to over-reliance on traditional method of production and processing (which results into low quantity and poor quality oil), and the discovery of crude oil in a commercial quantity among others (Alabi et al., 2020; Akangbe et al., 2011). Nwalieji and Ojike (2018) also stated that Nigeria did not only stop exporting palm oil, but also became a net importer of palm oil even from Malaysia that took the seedlings from her. According to Nwalieji and Ojike (2018), the growth in oil palm has stagnated at 930,000 MT since 2013, while the consumption of palm oil in Nigeria amounts to 2.0 million MT per annum and the shortage in oil palm industry is estimated to be around $1,070,000$ MT annually. This creates a very serious challenge not just for the manufacturing sector that uses it as input, but also human consumption.

Alabi et al. (2020) also identified harvesting, threshing, fruit loosening, boiling, digestion, pressing/oil extraction, clarification and packaging/storage as major oil palm fruit processing activities, which are done manually, except the digestion or pounding of cooked fruits, which is either done mechanically or using electrical digester equipment. Among the small- scale producers, traditional or semi-mechanized methods are also used for oil extraction from the fresh fruit bunch (Olagunju, 2008).

Based on the dwindling trend in oil palm production and processing in Nigeria, despite its contribution to the economy, coupled with aging rural farming population in Nigeria, it is becoming imperative to integrate youths into agricultural activities, especially oil palm fruit processing by providing incentives, such as access to credit, capacity building and provision of new technology cum processing facilities. This is because youth, apart from being mentally active citizens and capable of revitalising the sector, their participation in the sector is also important for increasing skills, knowledge, confidence, self-reliance and opportunity to collaborate and engage in sustainable agricultural development.

Several studies (Alabi et al., 2020, Nwalieji and Ojike, 2018, Adesiji et al., 2016) focused on in oil palm processing among farmers and processors, while studies conducted by Thomas and Eforuoku (2016), Adisa et al. (2017) and Akpan et al. (2015) centred on youth participation in agricultural production activities. However, there is dearth of information on rural youth involvement in oil palm fruits processing activities in Nigeria, especially in the study area. Hence, 
this study sought to assess the involvement of youths in oil palm fruit processing activities in Ondo State, Nigeria: it specifically described the socio-economic characteristics of youths involved in oil palm fruit processing activities; determined their level of involvement; examined their perception and identified constraints associated with their involvement. One hypothesis stated in null form as there is no significant relationship between socio-economic characteristics and youth involvement in oil palm fruit processing activities was tested in the study.

\section{Theoretical framework}

Theoretical proposition for the study was deeply rooted in rational choice theory developed by James $\mathrm{S}$. Coleman in 1990, which its basic principles are derived from neoclassical economics (as well as utilitarianism and game theory (Levi et al., 1990; Lindenberg, 2001; Simpson, 2007). According to https://phdessay.com/a-syudy-on-fastfood/, rational choice theory focused on actors where actors are seen as being purposive, or as having intentionality. That is, actors have ends or goals toward which their actions are aimed. It argued that rational actors are seen as having four basic elements: preferences (or values, utilities) and action is undertaken to achieve objectives that are consistent with an actor's preference hierarchy; actors'range of alternatives are constrained by the scarcity resources in the environment or by institutions that provide both positive and negative sanctions within, which they make their decisions; possession of complete information about their values; the various courses of action through which actors can pursue them (Emerson, 1976; Friedman and Hechter, 1988). Therefore, this theory is applicable to this study on the premises that youth are involved this enterprise based on the fact that they have intention or purpose of engaging in any action, in case of oil palm fruit processing activities, which could be for enhancing their income, serve as means of livelihood and promoting food security out of different alternatives open to them within their communities. These youths have to take into consideration resources available to them and access to these resources, such as: modern processing facilities, credit facilities and access extension services; institutional constraints, which provide both positive and negative sanctions that serve to encourage certain actions and discourage others; having full information about oil palm fruit processing activities and other economic activities to make purposive choice among the alternative courses of action open to them in the communities.

\section{MATERIALS AND METHODS}

The study was carried out in Ondo State, which is located in the Southwest geopolitical zone of Nigeria. The state has 18 local government areas (LGAs). A multi-stage sampling procedure was used to select respondents (youths) that were 


\section{J.O. AYINDE, M. FAMAKINWA, B.O. AKEREDOLU}

involved in oil palm fruit processing activities. At the first stage, three LGAs were purposively selected, namely Owo, Ondo East and Idanre LGAs based on the prevalence of oil palm production and processing in their areas. At the second stage, $10 \%$ of oil palm fruit processing rural communities were proportionate selected, which translated to five, four and three communities from Owo, Ondo East and Idanre LGAs, respectively, making a total of 12 rural communities. Primary data were collected through questionaires. Closed-ended questions were used to elicit quantitative data on socio-economic characteristics, their perception, constraints affecting youth involvement and their level of involvement. Data collected were analysed through the use of Statistical Package for the Social Sciences (SPSS) version 23. Descriptive statistical techniques, like frequency counts, percentages, means and standard deviation, were used to summarise data collected, while Chi-square and Pearson Product Moment Correlation analyses were used to draw inference on the hypothesis.

Involvement of youth in oil palm fruit processing activities was the dependent variable for this study was. This was conceptualised as the frequency of involvement, which was measured by asking the respondents to indicate how frequent they were involved in oil palm fruits processing activities on a four-point Likert-type scale of always (3), occasionally (2), rarely (1), and not at all (0) as employed by Alabi et al. (2020). Respondents' involvement was categorized into low, moderate and highlevel using equal interval method. Perception of the youth towards their involvement in oil palm fruit processing activities was measured by asking the respondents to react to 14 perceptional statements on a five-point Likert rating scale from Strongly Agree (5 points) to Strongly isagree (1 point) for the positive statements and reverse for the negative statements. Cut-off point of 3 was used to categorise their perception to favourable and unfavourable. Constraints militating against their involvement in oil palm fruit processing activities was measured using a four point Likert types scale of not severe (NS) [0 point], less severe (LS) [1 point], severe (S) [2 point], much severe (MS) [3 points] and very much severe (VMS) (4 points) These values were added and divided by 4 to get the mean scores of 2.5 .

\section{RESULTS AND DISCUSSION}

\section{Socio-economic characteristics}

Results in Table 1 show that mean age of the youths that are involved in oil palm fruit processing activities was $27.2 \pm 2.6$ years. This implies that most of these respondents were creative, energetic, innovative proneness and are likely to be more productive in economic enterprises, these qualities could enhance their involvement in oil palm activities. This is similar to the findings of Alao et al. (2014) and Adisa et al. (2017), which reported that the mean age of youth involved in vegetable production was about $28.3 \pm 5.5$ years. Majority $(63.3 \%)$ of the respondents were males; indicating male dominate the youth participants in oil palm fruit processing activities in the study area, possibly because some of the processing activities are stressful. This agrees with the findings of Ohimain et al., (2014), Ajayi and Solomon (2010) and Ekine and Onu (2008), who reported that more males 
than females were involved in oil palm processing. Majority (63.4\%) of the respondents were married, indicating married youth were more involved in oil palm processing activities. This is in line with findings of Thomas and Eforuoku (2016), that majority of the youth involved in agricultural programme in Ondo State were married.

Results further reveal that majority (95.8\%) of them had one form of education or the other, as most of them had completed secondary school, indicating high level of education and this could have positive implications on their attitude towards adoption of improved methods of processing of oil palm fruit. Olagunju (2008) had earlier observed that education will facilitate the adoption of innovations that will improve palm oil processing activities. The finding disagrees with Akangbe et al. (2011), who ascertained that there was a low level of education among oil palm processors in Nigeria. Higher percentage $(54.7 \%)$ of the respondents indicated that their mean household size was $4 \pm 2$ people, implying small household size, which may be due to their age and this could only guarantee few family labour for their processing activities. The finding similar to the findings of Akpomuvia (2010) assertion that a range of $4-6$ members constitute the modal household size in rural areas of Nigeria.

The mean length of engagement in processing activities was $5.1 \pm 2.7$ years, suggesting that respondents were relatively new in the enterprise and this may have serious implication on their ability to make sound decisions as regards oil palm fruit processing activities. About $60 \%$ of the respondents had mean labour size of $3 \pm 1$ workers. This implies they were operating on a small scale. Also, majority $(81.9 \%)$ of the respondents indicated personal saving as the major source of capital to finance the enterprise. This implies that most of the respondents in the study area depend on informal sources of credits to finance their enterprise. This is similar to the finding of Adam and Bidoli (2017), that majority of rural dwellers make use of personal saving as a start-up capitals for agrobusinesses. This could have a negative implication on the ability of rural youths to acquire and utilize modern equipment needed for oil palm fruit processing activities. The result show that respondents mostly received information on oil palm processing through friends/neighbours (91.6\%) and radio $(90.2 \%)$. The results indicate that most of the respondents had multiple sources of information, which might influence their better understanding and knowledge of the activities they involved in. Higher percentage $(59.2 \%)$ of respondents realized less than $\$ 20,000$ monthly from oil palm processing activities with a mean monthly income of $\$ 19,083.33 \pm 5,461.25$. This suggests that respondents earned above the national minimum wage of $\$ 18,000$ (USD 50) per month for the least paid in worker Nigeria before 


\section{J.O. AYINDE, M. FAMAKINWA, B.O. AKEREDOLU}

recent pronouncement of $\$ 30,000$, that is yet to be effective across the country, indicating that oil palm processing is a lucrative and profitable enterprise in Nigeria, as observed by Adeniyi et al. (2014) and Emokaro and Ugbekile (2014). There is the need for scaling up the income potentials of the enterprise to make it more attractive to the unemployed rural youths, thereby minimize ruralurban migration. This is similar to the findings of Adesiji et al. (2016), who reported that the monthly mean income of oil palm processors in Kogi State, Nigeria was of $18,421.98$.

Table 1 - Selected socio-economics characteristics of respondents

\begin{tabular}{lllll}
\hline Socio-economic variables & Frequency & Percentage & Mean & S.D. \\
\hline Age & & & & \\
\hline $15-20$ & 5 & 4.2 & & \\
\hline $21-25$ & 27 & 22.5 & 27.23 & 2.56 \\
\hline$>26$ & 88 & 73.3 & \\
\hline Sex & 76 & 63.3 & \\
\hline Male & 44 & 36.7 & \\
\hline Female & & & \\
\hline Marital status & 39 & 32.5 & \\
\hline Single & 76 & 63.4 & \\
\hline Married & 5 & 4.2 & \\
\hline Divorced & & & \\
\hline Household size & 22 & 18.3 & \\
\hline $1-2$ & 65 & 54.2 & 4.00 \\
\hline $3-5$ & 33 & 27.5 & \\
\hline$>5$ & & & \\
\hline Years in processing & 87 & 72.5 & \\
\hline $1-5$ years & 22 & 18.3 & 5.09 \\
\hline $6-10$ years & 11 & 9.2 & \\
\hline$>10$ & & & \\
\hline Level of education & 5 & 4.2 & \\
\hline No formal education & 18 & 15.0 & \\
\hline Primary education & 90 & 79.2 & \\
\hline Secondary education & 7 & 5.8 & \\
\hline Tertiary education & 71.67 \\
\hline Number of labour & & & \\
\hline$<3$ & 38 & 31.7 & \\
\hline $3-5$ & 71 & 59.2 & 3.23 \\
\hline$>5$ & 11 & 9.1 & \\
\hline Source of capital & & & \\
\hline Personal savings & 71 & 59.2 & \\
\hline Bank loans & 5 & 4.2 & \\
\hline Cooperatives & 22 & 18.2 & \\
\hline Relatives/friends & 5 & 4.2 & \\
\hline Salary earnings & 17 & 14.2 & \\
\hline Association/Group & & 36.7 & \\
\hline Yes & 44 & & \\
\hline & & \\
\hline
\end{tabular}


YOUTHS' INVOLVEMENT IN OIL PALM FRUIT PROCESSING ACTIVITIES

\begin{tabular}{|c|c|c|c|c|}
\hline No & 76 & 63.3 & & \\
\hline \multicolumn{5}{|c|}{ Income (I \$ US = $\$$ 360) } \\
\hline$<\# 20,000$ & 71 & 59.2 & & \\
\hline $\mathrm{A} 20,000-\mathrm{N} 40,000$ & 38 & 31.7 & A19,083.33 & $\mathrm{A} 5,461.25$ \\
\hline$>\mathrm{N} 40,000$ & 11 & 9.1 & & \\
\hline \multicolumn{5}{|c|}{ *Sources of information } \\
\hline Extension agent & 27 & 22.5 & & \\
\hline Research institutes & 11 & 9.2 & & \\
\hline Friends/Neighbours & 110 & 91.6 & & \\
\hline Television & 55 & 45.8 & & \\
\hline Radio & 109 & 90.9 & & \\
\hline Newspaper & 5 & 4.2 & & \\
\hline
\end{tabular}

*Multiple response; Source: Field survey, 2019

Perception of respondents towards involvement in oil palm processing activities

Based on the cut-off point of 3 and the scale of measurement, which is vice versa for positive and negative statements, results in Table 2 show that respondents favourably perceived positive statements that youth involvement in oil palm fruit processing activities are very lucrative and highly profitable $(\bar{x}=4.65)$; youth involvement in oil palm fruit processing activities provide employment opportunities $(\bar{x}=4.35)$; youth involvement oil palm fruit processing activities provides a lot raw materials to the industry $(\bar{x}=$ 4.22) among others. However, youths were favourably perceived the negative statements that oil palm fruit processing activities require expensive equipment and machinery $(\bar{x}=1.96)$; oil palm fruit processing activities is labour intensive $(\bar{x}=$ 1.84); poor pricing of oil palm products is major challenge to youth involvement $(\bar{x}=1.72)$ and people in this community look down on youths involved in oil palm processing $(\bar{x}=$
1.62) among others. The results show that respondents supported all the positive perceptional statements, while they disagreed to most of the negative statements implying that the youth in the study area perceived involvement in oil palm fruit processing activities as a welcome development; however, functional credit facilities should be provided by agricultural development stakeholders, including financial institutions and government, to boost and sustain their interest in the enterprise.

Fig. 1 shows that higher percentage $(57.9 \%)$ of the youths favourably perceived their involvement in oil palm fruit processing activities, while $42.1 \%$ indicated unfavourable perception. This implies that larger percentage of youth in the study area had favourably disposition towards involvement in oil palm fruit processing activities, as favourable perception may likely influence their involvement in oil palm processing activities. In order to sustain the interest of the youth in these activities, there is the need for the government to provide enabling 


\section{J.O. AYINDE, M. FAMAKINWA, B.O. AKEREDOLU}

environment for them. This gives credence to the submission of Thomas and Eforuoku (2016), that that majority of youth had favourable disposition to agricultural programmes in Ondo State

Table 2 - Respondent's perception about oil palm fruit processing

\begin{tabular}{lc}
\hline Statements & Ranked mean $(\bar{x})$ \\
\hline $\begin{array}{l}\text { Oil palm fruit processing activities are very lucurative and } \\
\text { highly profitable }\end{array}$ & 4.65 \\
\hline $\begin{array}{l}\text { Oil palm fruit processing activities provide empoyment } \\
\text { opportunities }\end{array}$ & 4.35 \\
\hline $\begin{array}{l}\text { Oil palm fruit processing activities provides a lot raw } \\
\text { materials to the industry }\end{array}$ & 4.22 \\
\hline $\begin{array}{l}\text { Involvement in oil palm activities can standard of living of } \\
\text { people }\end{array}$ & 4.1 \\
\hline $\begin{array}{l}\text { Oil palm fruit processing activities enhance growth and } \\
\text { development of rural area }\end{array}$ & 4.02 \\
\hline $\begin{array}{l}\text { Involvement in oil palm fruit processing is way of reducing } \\
\text { poverty }\end{array}$ & 3.88 \\
\hline $\begin{array}{l}\text { Oil palm fruit processing activities provides a lot raw } \\
\text { materials to the industry }\end{array}$ & 3.68 \\
\hline $\begin{array}{l}\text { My family encourage my involvement in oil palm fruit } \\
\text { processing activities }\end{array}$ & 3.76 \\
\hline $\begin{array}{l}\text { Oil palm fruit processing activities require expensive } \\
\text { equipment and machinery }\end{array}$ & 1.96 \\
\hline \begin{tabular}{l} 
Oil palm fruit processing activities is labour intensive \\
\hline $\begin{array}{l}\text { A lot of hazards are associated with oil palm processing } \\
\text { activities }\end{array}$
\end{tabular} & 1.84 \\
\hline $\begin{array}{l}\text { Poor pricing of oil palm products is major challenge to youth } \\
\text { involvement }\end{array}$ & 1.78 \\
\hline $\begin{array}{l}\text { People in this community look down on youths involved in oil } \\
\text { palm processing }\end{array}$ & 1.72 \\
\hline $\begin{array}{l}\text { A lot of hazards are associated with oil palm processing } \\
\text { activities }\end{array}$ & 1.62 \\
\hline
\end{tabular}

Cut off point = 2.50; Source: Field survey, 2019

Results in Table 3 show that with the cut-off point of 1.50 , respondents among others were always involved in picking of fresh fruit bunches $(\bar{x}=2.71)$, package $(\bar{x}=2.60)$ and gathering of bunches $(\bar{x}=2.50)$. They were often involved in packaging $(\bar{x}=2.24)$ and clarification of oil $(\bar{x}=1.46)$ and harvesting $(\bar{x}=1.43)$. The result indicates that respondents were less involved in digestion of boiled fruits, clarification of oil and harvesting of fresh bunches. Youths were least involved in harvesting of bunches because they were still using traditional method of harvesting, which is highly risky and hazardous.

Fig. 2 shows that $9.7 \%$ of the respondents were highly involved in oil palm fruits processing activities, majority $(72.5 \%)$ were moderately involved, while $17.8 \%$ had low level of involvement oil palm fruit processing activities. This results 
implies very few respondents were highly involved in oil palm fruit processing activities; this is because majority of oil palm processors in the study area still depend on traditional method of processing as reported by Alabi et al. (2020), which discourages youth participation. It is therefore imperative for the agricultural stakeholders including government should encourage the youth involvement by providing modern processing facilities at subsidize rate and create enabling environment to enhance their involvement in oil palm processing enterprises.

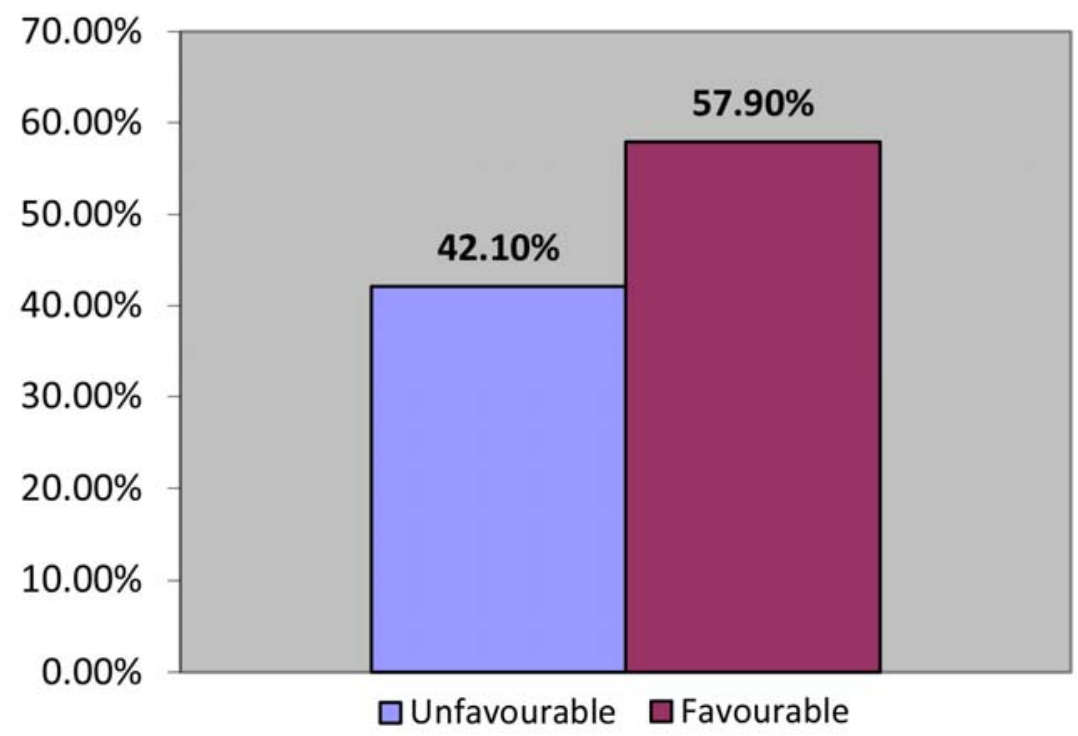

Figure 1 - Level of perception of the youths

Table 3 - Respondents' involvement in oil palm fruit processing activities

\begin{tabular}{ll}
\hline Activities & Mean \\
\hline Picking of fresh fruit bunches & $2.71^{* *}$ \\
\hline Packaging & $2.60^{* *}$ \\
\hline Gathering of bunches & $2.50^{* *}$ \\
\hline Storage & $2.27^{* *}$ \\
\hline Marketing & $2.15^{* *}$ \\
\hline Chopping of bunches & $1.82^{* *}$ \\
\hline Removal of debris & $1.69^{* *}$ \\
\hline Boiling of palm fruits & $1.58^{* *}$ \\
\hline Extraction of crude oil & $1.51^{* *}$ \\
\hline Digestion of bolied fruits/foot trampling of boiled fruits & 1.47 \\
\hline Clarification of oil & 1.46 \\
\hline Harvesting of palm fruits & 1.43 \\
\hline
\end{tabular}

Cut-off point $\geq 1.5$; Source: Field survey, 2019 


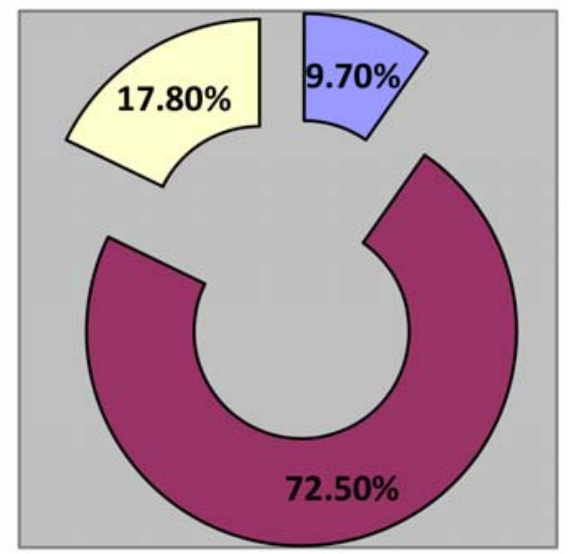

$\square$ High $\square$ Moderate $\square$ Low

Figure 2 - Level of youth involvement in oil palm processing activities

\section{Constraints associated with} youth involvement in oil palm fruit processing activities

Table 4 reveals that with the cutoff point of 2.5, respondents identified major constraints associated with their participation in oil palm fruit processing activities, as inadequate processing facilities $(\bar{x}=3.65)$ was the prime constraint to oil palm processing activities. This confirms the findings of Alabi et al. (2020) and Adesiji et al. (2016), that established that lack of modern processing equipment as the prime challenge facing oil palm processing activities in Nigeria. Lack of funds/Inadequate credit facilities $(\bar{x}=3.65)$ took second position among the constraints; this is because youth are poor and do not have access to credit facilities to acquire modern equipment and other processing inputs to enhance their processing activities. This substantiates the reports of Alabi et al. (2020), who established that inadequate funds constitutes a major problem inhibiting oil palm processing activities in Nigeria. Inefficiency processing method/technology $(\bar{x}=3.15)$ among others is another constraints that is equally important. As a result of this, many of the youths still depend on the manual/crude processing methods, which make oil palm processing activities laborious, tedious, unattractive, inefficient and lead to poor quality, and low quantity oil palm products. This is in tandem with findings of Akangbe et al. (2011), who identified crude and poor palm oil extraction technology as one of the major constraint to oil palm processing, Price of oil palm products, especially palm oil, is not stable at the local markets due to activity of middlemen, demand and unstable production costs and high cost of transportation also constitute a major constraint due to poor condition of rural roads leading to many farms and villages, which make it difficult for transporting oil palm products to the markets, and the traditional nature of palm oil production requires much labour, which are scarce in supply thereby slowing down productivity. This is in line with the reports of Nwalieji and Ojike (2018), who identified poor and inadequate transportation, poor pricing of oil palm products and inadequate labour supply as some of the prominent constraints to oil palm processing activities. 


\section{YOUTHS' INVOLVEMENT IN OIL PALM FRUIT PROCESSING ACTIVITIES}

Table 4 - Constraints to oil palm fruit processing activities by youth

\begin{tabular}{lc}
\hline Statement & Ranked mean $(\overline{\boldsymbol{x}})$ \\
\hline Lack of modern processing equipments & $3.36^{\star *}$ \\
\hline Lack of funds/credit facilities & $3.32^{\star *}$ \\
\hline Inefficiency processing method/technology & $3.15^{\star *}$ \\
\hline High cost of transportation & $2.98^{\star *}$ \\
\hline Unfavourable market situation & $2.64^{* *}$ \\
\hline Inadequate and high cost of labour & $2.56^{\star *}$ \\
\hline Poor extension services & 2.25 \\
\hline Lack of government support & 1.59 \\
\hline Hazards associated with processing & 1.43 \\
\hline Poor storage facilities & 1.46 \\
\hline There is low household acceptance & 1.41 \\
\hline
\end{tabular}

Cut off point $=2.5 ;{ }^{* *}$ major constraints; Source: Field survey, 2019

\section{Testing of hypothesis}

Results in Table 5 reveal that marital status $\left(\chi^{2}=11.000, p \leq 0.05\right)$, level of formal education $\left(\chi^{2}=10.476\right.$, $p \leq 0.01)$, primary occupation of the respondent $\left(\chi^{2}=19.643, \mathrm{p} \leq 0.05\right)$ and sources of labour $\left(\chi^{2}=12.541, p \leq 0.05\right)$ had significant association to youth involvement in oil palm fruit processing activities. This implies that these variables determine the youth involvement in oil palm fruit processing activities.

Table 5 - Result of Chi-square analysis between socio-economic characteristics and youth involvement in oil palm fruit processing activities $\mathbf{g}$

\begin{tabular}{llll}
\hline Variable & $\mathbf{x}^{2}$ & D.f & p-value \\
\hline Sex & 1.473 & 2 & 0.479 \\
\hline Marital status & 11.0 & 4 & 0.027 \\
\hline Religion & 4.714 & 2 & 0.095 \\
\hline Formal education & $10.476^{* *}$ & 2 & 0.005 \\
\hline Primary occupation & $19.643^{*}$ & 10 & 0.033 \\
\hline Social affiliation & 3.896 & 4 & 0.420 \\
\hline Sources of capital & 8.832 & 10 & 0.548 \\
\hline Sources of labour & $12.541^{*}$ & 4 & 0.014
\end{tabular}

"Correlation is significant at the 0.01 level; "Correlation is significant at the 0.05 level; Source: Field survey, 2019

The results in Table 6 show that number of labour $(\mathrm{r}=0.7460, p \leq 0.01)$ and monthly income $(\mathrm{r}=0.601, p \leq 0.01)$ had positive and significant relationship to the youth involvement in oil palm fruit processing activities. The findings imply that the higher the number of labours employed by the youth involved in oil palm fruit processing activities, the more their involvement in oil palm fruit processing activities. Also, the higher the income the youth realized from oil palm fruit processing activities, the 
higher their involvement. This is similar to the findings of Akpan et al. (2015), who reported that income had relationship with youth participation in agricultural activities. Based on these findings, null hypothesis is rejected, while alternative the hypothesis is accepted.

Table 6 - Result of Pearson's correlation analysis between socio-economic characteristics and youth involvement in oil palm fruit processing activities

\begin{tabular}{lcc}
\hline Variables & $\begin{array}{c}\text { Pearson correlation } \\
\text { coefficient }(\mathbf{r})\end{array}$ & $\boldsymbol{p}$-value \\
\hline Age & 0.208 & 0.354 \\
\hline Household size & -0.226 & 0.312 \\
\hline Years of oil palm processing & -0.385 & 0.077 \\
\hline Number of labour & $0.741^{* *}$ & 0.000 \\
\hline Years of experience & -0.267 & 0.229 \\
\hline Income & $0.601^{* *}$ & 0.003 \\
\hline Correlation is significant at the 0.01 level; Source: Field survey, 2019
\end{tabular}

\section{CONCLUSIONS}

Based on the findings of the study, youth involvement in oil palm fruits processing activities was moderate and many of them were favourably perceived their involvement in oil palm fruit processing activities. However, several constraints were identified by the youth that impede their involvement in these activities include lack of modern processing facilities, lack of funds/inadequate credit facilities and inadequate processing technology. Also, income from oil palm fruit processing activities and numbers of labours were found to be significantly related to youth involvement in oil palm fruit processing activities. It is therefore recommended that agricultural development stakeholders including government and financial institutions should provide adequate, and functional credits facilities to these youths in order to encourage/promote their involvement. Appropriate and affordable harvesting machines and processing facilities should be fabricated by relevant stakeholders, such as agricultural engineers and local fabricators. Also, enabling environment through provision of good road network to rural areas should be provided by the governments at all levels. Finally, capacity building should be provided to the youth through adequate training on modern processing technology to enhance their involvement in oil palm fruit processing activities.

\section{REFERENCES}

Adam, A.G. \& Bidoli, T.D. (2017). Assessment of gender roles among agro-inputs entrepreneurs in North West Nigeria (Jibril et al., Eds.). Proceedings of the $31^{\text {st }}$ Annual National Conference of the Farm Management Association of Nigeria held at Abubakar Tafawa Balewa University, Bauchi, Nigeria, $9^{\text {th }}-12^{\text {th }}$, October, pp. 274-280. 
Adeniyi, O.R., Ogunsola, G.O. \& Olawusi, D. (2014). Methods of oil palm processing in Ogun State, Nigeria: a resource use efficiency assessment. AIJCR, 4(8): 173-179.

Adesiji, G.B, Komolafe, S.E., Kayode, A.O. \& Paul, A.B. (2016). Socioeconomic benefits of oil palm value chain enterprises in rural areas of Kogi State, Nigeria PAT June, 12(1): 36-47 Available online at www.patn sukjournal.net/currentissue

Adetola, S. (2015). Palm oil importation: a strategic stabiliser for palm oil industry in Nigeria. Retrieved on 4/09/19 from http://www.thisdayli ve.com/articles/palm-oil-importationa-strategic-stabiliser-for-palm-oilindustry-innigeria/198476/

Adisa, B.O., Ojerinde, O.A. \& Famakinwa, M. (2017). Factors influencing youths' utilization of underutilized indigenous vegetable innovations as a livelihood strategy in Southwestern Nigeria Trop.Agr. Res.Ext., 20 (3/4): 105-114, DOI: 10.4038/tare.v20i3-4.5396

Ajayi, M.T., Banmeke T.O. A. \& Solomon, O. (2010). Information needs of oil palm farmers in Esan Central Local Government Area of Edo state, Nigeria. Nigerian Journal of Rural Extension and Development, 3(1): 45-56.

Agwu, A.E. (2006). Adoption of improved oil palm production and processing technologies in Arochukwu local government area of Abia State, Nigeria. Agro-Science, 5(1): 25-35, DOI: 10.4314/as.v5i1.1541

Akangbe, T.A., Adesiji, G.B., Fakayode, S.B. \& Aderibigbe, Y.O. (2011). Towards palm oil selfs-ufficiency in Nigeria: constraints and training needs nexus of palm oil extractors. J.Hum.Ecol.., 33(2): 139-145, DOI: 10.1080/09709274.2011.11906356

Akinbile, L.A., Hussain, L.A. \& Yekini, O.T. (2008). CD/CBO participation in community base poverty reduction projects in selected communities in Ekiti State. Nigerian J. Rural Sociol.,
8 (1): 41-47, DOI: 10.1855/rjoas. 2015-07.05

Akpan, S.B. Patrick, I.V. James, S.U. \& Agom, D.I. (2015). Determinants of decision and participation of rural youth In agricultural production: a case study of youth in Southern region of Nigeria. RJOAS, 7(43), Available online at https://rjoas.com/ issue-2015-07/article_05.pdf (Accessed July, 2019)

Akpomuvia, O.B. (2010). Self-help as a strategy for rural development in Nigeria: A bottom-up Approach. JAPSS, 2(1): 88-111.

Alabi, D.L. \& Famakinwa, M. (2016). Assessment of financial resource allocation of rural youth entrepreneurs in Osun State, Nigeria. Proceedings of the $13^{\text {th }}$ International Research and Development Network of Children and Youth in Agriculture Programme in Nigeria (CYIAPnetwork), pp. 8-17.

Alabi, D.L, Famakinwa, M. \& Ogunjimi, S.I. (2017). Gender analysis of problems and prospects of rural household-based enterprises In Osun State, Nigeria. Scientific Papers Series "Management, Economic Engineering in Agriculture and Rural Development", 17(1): 3137.

Alabi, D.L., Famakinwa, M. \& Akinnawonu, O.E. (2020). Involvement of rural households in oil palm (Elaeis guineensis) fruits postharvest activities in Ondo State, Nigeria. J.Agric.Sci., 24(1): 42-53, DOI: $10.4314 /$ jae.v24i1.5

Alao, O.T., D.O. Torimiro \& J.O. Ayinde (2014). Perception of youth roles in agricultural innovation management system among arable crop farmers in farming communities of Osun State, Nigeria. Am.J.Exp.Agric., 5(2): 124-133. Article no. AJEA.2015.014. Available from: URL: http://science domain.org/issue/665

Aphunu, A. \& Atoma, C.N. (2010). Rural youth involvement in agricultural production in Delta Central 


\section{J.O. AYINDE, M. FAMAKINWA, B.O. AKEREDOLU}

Agricultural Zone: challenge to agricultural extension development in Delta State. J.Agric.Ext., 14(2): 46-47, DOI: 10.4314/jae.v14i2.64 123

Bahaman, A.S. Jeffrey, L.S. Hayrol Azril, M.S. \& Jegak, U. (2010). Acceptance, attitudes and knowledge towards agriculture economic activity between rural and urban youth: the case of contract farming. J.Appl.Sci., 10(19): 2310-2315, DOI: 10.3923/ jas.2010.23 10.2315

Chukwu, A.O. \& Nwaiwu, J.C. (2012). Evaluation of gender participation in palm oil processing in Ohaji Egbema Local Government Area of Imo State. Int.J.Agric.Rural Dev.,15(2): 972-975.

Ekine, D.I. \& Onu, M.E. (2008). Economics of small-scale palm oil processing in Ikwerre and Etche Local Government Areas of Rivers State, Nigeria. J.Agric.Soc.Res., 8 (2): 1-9, DOI: 10.4314/jasr.v8i2. 43342

Emerson, R.M. (1976). Social exchange theory. Annu.Rev.Sociol., 2(1): 335362.

Emokaro, C.O. \& Ugbekile, P. C. (2014). Economic analysis of oil palm processing in Ovia North East and Ikpoba-Okha local Government areas of Edo State, Nigeria. Nigerian J.Agric. Food Environ., 10(2): 70-78.

Eze, S.O., Nwoha, V.U. \& Adiele, O.S. (2014). Oil palm processing among farmers in Imo State: implications for market orientation and entrepreneurship in extension practice in Nigeria. J.Agric.Econ. Ext.Rural Develop., 2(7): 114-120.

Friedman, D. \& Hechter, M. (1988). The contribution of rational choice theory to macrosociological research. Sociol. Theory, 6(2): 201-218, DOI: 10.2307/202116

Gourichon, H. (2013). Analysis of incentives and disincentives for palm oil in Nigeria. Technical notes series, MAFAP, FAO, Rome. http://www. fao. org/mafap.
Levi, M., Cook, K.S., O'Brien, J.A. \& Faye, H. (1990). The limits of rationality. In: K.S. Cook and M. Levi (Eds.), The Limits of Rationality. Chicago: University of Chicago Press.

Lindenberg, S. (2001). Social rationality versus rational egoism. In: Jonathan $\mathrm{H}$. Turner (Ed.), Handbook of Sociological Theory. New York: Kluwer Academic/Plenum Publishers: 635-668.

National Population Commission (NPC) (2013). Nigeria's unemployment rate rises to $23.9 \%$ - NPC, Punch newspaper, October 13, 2013.

Nwachukwu, I. (2008). Youth development for agriculture and rural transformation in Nigeria. Proceedings of the $7^{\text {th }}$ Annual Congress of the Nigeria Rural Sociological Association held at NRCRI, Umidike 19-22 ${ }^{\text {nd }}$ August, pp. 11-14.

Nwalieji, H.U. \& Ojike, H.U. (2018). Characteristics of small-scale palm oil production enterprise in Anambra State. J.Agric.Ext., 22(1): 22-34, DOI: 10.4314/jae.v22i1.3

Ohimain, E.I., Emeti, C.I., Sylvester, C., Izah, S.C. \& Eretinghe, D.A. (2014). Small-scale palm oil processing business in Nigeria: a feasibility study. Greener Journal of Business and Management Studies, 4(3): 7082, DOI: 10.15580/GJBMS.2014.3. 012714071

Olagunju, F.I. (2008). Economics of palm oil processing in Southwestern Nigeria. IJAERD, 4(8): 125-133.

Onwumere, J., Onwusiribe, N. \& Iheanatu, C. (2014). Value chain analysis of palm fruit production and processing in Abia State, Nigeria. Asian J.Agric.Ext.Econ.Sociol., 3(3), 243-256, DOI: 10.9734/AJAEES/ 2014/9461

Osei-Amponsah, C., Agbotse, P., Swanzy, F. \& Stomph, T.J. (2018). Role of small- scale enterprises in agricultural development ggendas: Insights from oil palm processing 
enterprises in the Kwaebibirem district of Ghana. Ghana J.Agric. Sci., 52: 131-144.

Ovwigho, B.O. \& Ifie, P.A. (2009). Attitude of youth to agricultural development programmes in Ughelli South Local Government Area of Delta State, Nigeria. Journal of Agricultural Extension 13(2): 67-69, DOI: 10.4314/jae.v13i2.53898

Simpson, B. (2007). Rational choice theories. In: George Ritzer (Ed.), The Blackwell Encyclopedia of Sociology. Oxford: Blackwell: 37943799.

Valerie, L (2009). Youth in agriculture: challenges and opportunities.
Proceedings of the $30^{\text {th }}$ Regular Meeting of the Conference of Heads of Government of the Caribbean Community, 2-5 July 2009, Georgetown, Guyana.

United States Department of Agriculture (USDA, 2000). Oil Palm production, Exports and Imports Statistics

https://www.modishproject.com/assess ment-women-palm-processing/ Assessment of women in oil palm processing https://phdessay.com/asyudy-on-fast-food/, A study of fast food.

https://phdessay.com/a-syudy-on-fastfood/, A study of fast food 